\title{
Probiotic strains of lactobacilli and bifidobacteria alter pro- and anti-inflammatory cytokines production in rats with monosodium glutamate-induced obesity
}

\author{
T.M. Falalyeyeva ${ }^{1}$, I.V. Leschenko ${ }^{1}$, T.V. Beregova ${ }^{1}$, L.M. Lazarenko ${ }^{1,2}$, O.M. Savchuk ${ }^{1}$, \\ L.M. Sichel ${ }^{2}$, O.I. Tsyryuk ${ }^{1}$, T.B. Vovk ${ }^{1}$, M.Ya. Spivak ${ }^{2,3}$ \\ ${ }^{1}$ Taras Shevchenko National University of Kyiv, Kyiv, Ukraine; \\ ${ }^{2}$ D.K. Zabolotny Institute of Microbiology and Virology, National Academy of Sciences of Ukraine, \\ Kyiv, Ukraine; \\ ${ }^{3}$ LCL «Diaprof», Kyiv, Ukraine, e-mail: LazarenkoLM@yandex.ua
}

\begin{abstract}
The aim of this study was to investigate the effect of probiotic strains of Lactobacillus casei IMV B-7280, Bifidobacterium animalis VKL, B. animalis VKB on the pro- and anti-inflammatory cytokines production in Wistar male rats with monosodium glutamate (MSG)-induced obesity. It was established that neonatal administration of MSG to rats leads to increasing levels of the interleukin (IL)-1 $\beta$ and IL-12, and to decreasing of the IL-4, IL-10 and tumor growth factor (TGF)- $\beta$ levels in the blood serum. After administration of the B. animalis VKL - B. animalis VKB - L. casei IMV B-7280 composition to obese rats the level of the $I L-1 \beta$ in blood serum wasn't differ from that in the obese rats, that didn't receive of the probiotic bacteria. But there was no statistically significant difference comparing with intact rats. The level of the IL-12B p40 in blood serum was decreased under influence of the B. animalis VKL - B. animalis VKB - L. casei IMV $B-7280$ composition $(18.9 \%, p<0.05)$ and B. animalis VKL $(10.5 \%, p<0.05)$ compared with obese rats, not receiving probiotic bacteria, but remained higher than in intact animals. After administration to obese rats of the B. animalis VKL - B. animalis VKB - L. casei IMV B-7280 composition the levels of the IL-4, IL10 and TGF- $\beta$ increased in blood serum comparing with obese rats, not receiving probiotic bacteria. The level of the IL-10 also increased under influence of the B. animalis VKB, and IL-4 - under influence of the L. casei IMV B-7280. Our results suggest that these probiotic bacteria and probiotic composition are able to down-regulation the inflammation in rats with MSG-induced obesity but the strongest anti-inflammatory effects have probiotic composition. The ability of lactobacilli and bifidobacteria to alter the pro- and antiinflammatory cytokines production, opens perspectives to create new treatments for obesity and metabolic syndrome based on probiotics.

Key words: obesity; monosodium glutamate; Lactobacilli; Bifidobacteria; cytokines; rats.
\end{abstract}

\section{INTRODUCTION}

World Health Organization considers obesity as a global epidemic today. The onset of obesity is a complex process that involves genetic and environmental factors. It is often associated with metabolic syndromes (hyperglycemia, hypertriglyceridemia, dyslipidemia and hypertension) and development of several chronic complications such as cardiovascular diseases, type II diabetes, premature death, diseases of musculoskeletal system, hepatobiliary disease, and various tumor sites, including lung cancer, (C) T.M. Falalyeyeva, I.V. Leschenko, T.V. Beregova, L.M. Lazarenk breast cancer, uterine and ovarian cancer etc. $[1,2]$.

Obesity is a pathological state in neuroimmunomodulation. Thus, in the case of obesity, we can observe both systemic and vascular chronic low-grade inflammation in fat tissue, liver, and intestines, which is accompanied with the production of pro-inflammatory cytokines and other inflammatory markers in response to changes in metabolic homeostasis associated with metabolic overload of cell nutrients [3]. Additionally, monosodium glutamate (MSG) O.M. Savchuk, L.M. Sichel, O.I. Tsyryuk, T.B. Vovk, M.Ya. Spivak 
induses the dysfunction of specific hypothalamic neurons and the activation of hypothalamicpituitary-adrenal axis that lead to violating of anorexigenic and thermogenic signals generated by such hormones as leptin and insulin, as well as rising of the corticosterone levels [4, 5]. This, in turn, may lead to abnormal regulation of body weight and obesity [4], that can also enhance the expression of inflammatory cytokines [6].

In the case of obesity, adipocytes secrete less amount of anti-inflammatory adiponectin. And we observed the increased expression of genes encoding cytokines, chemokines, and other inflammatory mediators through the activation of transcription factors (nuclear factor $\kappa \mathrm{B}(\mathrm{NF}-\kappa \mathrm{B})$, protein activator-1 (AP-1), signal transducer and activator of transcription 3 (STAT 3 ), and others) [7, 8]. Under such conditions, the pro-inflammatory tumor necrosis factor- $\alpha$ (TNF $\alpha$ ), interleukine-6 (IL-6), macrophage chemoattractants (MCP-1 and NAMPT), and leptin are produced to induce the pro-inflammatory response of immune cells. The immune cells (macrophages, neutrophils, and T-lymphocytes) secrete cytokines (TNF $\alpha$, IL-1 $\beta$, IL-6, and interferon- $\gamma$ ) in fat tissue. This can alter lipid storing in adipocytes, lipolysis, insulin response, glucose metabolism and adipokine production, and lead to ectopic fat deposition and systemic inflammation. Leptin plays a role in the activation of the immune system in obesity, therefore, may be one of the mediators, responsible for the low-grade systemic inflammation. It should be noted that leptin stimulates $\mathrm{CD} 4^{+} \mathrm{T}$-lymphocytes to produce the interferon- $\gamma$, which induces the adipocyte MHC II expression [2, 9]. However, some anti-inflammatory cytokines such as IL-10 and receptor antagonist IL-1 (IL-1RA) decrease [10].

Most studies established the imbalance of gut microbiota both in humans and in mice with obesity [11]. In the case of obesity the increased Firmicutes: Bacteroidetes ratio was found, and increased intestinal permeability was observed. After translocation of gut bacteria to other organs such as liver or adipose tissue, the bacterial lipopolysaccharides (LPS) in the bloodstream and organs activate pro-inflammatory cytokines production through activation of the Toll-like receptor 4 [2].

Increasing of the pro-inflammatory cytokines production together with rising of the corticosterone level in case of obesity is associated with obesity-related complications such as insulin resistance, hyperlipidemia, atherosclerosis $[12,13]$. Therefore, the influence on the pro-inflammatory cytokine production is an important strategy for the integrated personalized treatment of patients with obesity.

Certain probiotic bacteria were recently tested for their ability to affect obesity and metabolic syndrome. It was shown that probiotic strains are able to improve some biomarkers of obesity, including an imbalance in gut microbiota, hyperlipidemia, hyperglycemia, oxidative stress and inflammation. The use of probiotics is justified by the fact that in the case of obesity, the number of Lactobacilli and Bifidobacteria in the intestines reduces dramatically and gut microbiota have an important role in the regulation of the energy homeostasis and fat storing. In the same time, such altered gut microbial ecosystems are associated with increased prevalence of metabolic and immune disorders in animals and humans [14, 2, 11]. These results suggest the potential using of probiotics in order to alleviate the occurrence of metabolic diseases by less radical approach comparing with drugs or hormone therapy. We showed that preliminary selected and characterized probiotic strains of Lactobacillus casei IMV B-7280, Bifidobacterium animalis VKL, B. animalis VKB and their various compositions have high ability to balance immune response to infectious diseases [15] and are able to effectively prevent MSG-obesity in rats [16].

Thus, the aim of this study was to investigate the influence of probiotic strains of $L$. case $i$ IMV B-7280, B. animalis VKL, B. animalis VKB (separately) and the $B$. animalis VKL - B. animalis VKB - L. casei IMV B-7280 
composition on the pro- and anti-inflammatory cytokines production in rats with MSG-induced obesity.

\section{METHODS}

In our experiment, we used newborn rats (Wistar) $(\mathrm{n}=60)$. We administered monosodium glutamate (MSG) to the animals in a dose of 4 $\mathrm{mg} / \mathrm{g}$ of body weight subcutaneously on the $2^{\text {nd }}$, $4^{\text {th }}, 6^{\text {th }}, 8^{\text {th }}$ and $10^{\text {th }}$ day of life. Within 4 months after birth, rats with visceral obesity were on a standard diet.

In our study we used probiotic strains of L. casei IMV B-7280, B. animalis VKL and $B$. animalis VKB that were previously isolated from the intestines of healthy people and the B. animalis VKL - B. animalis VKB - L. casei IMV B-7280 (1:1:2) composition. L. casei IMV B-7280 is stored at the Depositary of the microorganisms at the Zabolotny Institute of Microbiology and Virology of the National Academy of Sciences of Ukraine.

Administration of probiotic strains in a dose of $5 \times 10^{9} \mathrm{CFU} / \mathrm{kg}(50 \mathrm{mg} / \mathrm{kg})$ intragastrically (i.g.) into obese rats was started at the age of 4 weeks just after weaning and lasted 3 months, wherein 2 weeks of introduction were alternated with 2 -week break. The experiment lasted 4 months. Rats were split into 6 groups of 10 animals. Wistar rats were split into 6 experimental groups (10 rats in each): 1) intact rats (control), 2) rats which received MSG (the MSG-group), 3) rats which received the $B$. animalis VKL - B. animalis VKB - L. casei IMV B-7280 (1:1:2) composition (the MSG-group + probiotic composition), 4) rats which received MSG and $B$. animalis VKL (the MSG-group $+B$. animalis VKL), 5) rats which received MSG and B. animalis VKB (the MSG-group $+B$. animalis VKB), and 6) rats which received MSG and $L$. casei IMV B-7280 (the MSG-group + L. casei IMV B-7280).

Serum cytokines (IL-1 $\beta$, IL-12Bp40, IL-4, IL-10, interferon- $\gamma$ and tumor growth factor- $\beta$ (TGF- $\beta)$ ) were quantified by ELISA immune assays with primary and secondary antibodies from Santa Cruz Biotechnology (USA).

All received digital data was processed through analysis of variance by using the Epi Info software (version 8.0) and "Statistica, 8.0". Obtained results were tested for normality of distribution using F Shapiro-Wilk test. If the data did not meet the normal distribution law, the comparison of two unrelated samples was performed by Mann-Whitney test. In the normal distribution, comparison of the difference between control and experimental measurements was performed using Student t-test for independent samples. The critical level of statistical significance for all tests was $\mathrm{P}<0.05$. Data is represented as mean value $(\mathrm{M})$ and the average standard error $(\mathrm{m})$ [17].

Ministry of Education and Science of Ukraine supported this study (Project No. F64/32-2016 (16DF036-03), 12.04.2016).

\section{RESULTS AND DISCUSSION}

In our study, administration of MSG to newborn rats was accompanied with the increasing production of IL- $1 \beta$ and IL-12Br40 proinflammatory cytokines (Table 1). We observed increased levels of the IL-1 $\beta(22.4 \%, \mathrm{P}<0.05)$ and IL-12 $(61.2 \%, \mathrm{P}<0.05)$ in blood serum of obese rats that indicates strengthening of the inflammatory processes in the case of MSG-induced obesity. On the other hand, the interferon- $\gamma$ production was not changed.

The probiotic strains of $B$. animalis VKL, $B$. animalis VKB and L. casei IMV B-7280 did not affect the level of the IL- $1 \beta$ in blood serum of obese rats comparing with the MSG-group. The level of the IL-1 $\beta$ in blood serum of these rats was $17.2 \%(\mathrm{P}<0.05), 23.6 \%(\mathrm{P}<0.05)$ and $20.6 \%(\mathrm{P}<0.05)$ higher vs intact rats.

However, after administration of the $B$. animalis VKL - B. animalis VKB - L. casei IMV B-7280 composition to obese rats the level of the IL-1 $\beta$ did not differ from that in the MSGgroup, but in the probiotic composition-group, there were no significant differences comparing 
Probiotic strains of lactobacilli and bifidobacteria alter pro- and anti-inflammatory cytokines production

Table 1. Concentration of the pro-inflammatory cytokines in the serum of the obese rats $(M+m, n=10)$

\begin{tabular}{l|ccc|}
\hline \multirow{2}{*}{ Groups of the rats } & \multicolumn{3}{c|}{ Level of the cytokines in serum, pg/ml } \\
\cline { 2 - 4 } \multicolumn{1}{|c|}{ IL-1 $\beta$} & IL-12B p40 & interferon- $\gamma$ \\
\hline Intact rats & $0.472 \pm 0.014$ & $0.808 \pm 0.025$ & $0.299 \pm 0.013$ \\
MSG-group & $0.578 \pm 0.032^{*}$ & $1.302 \pm 0.046^{*}$ & $0.317 \pm 0.019$ \\
MSG-group + probiotic composition & $0.510 \pm 0.022$ & $1.057 \pm 0.041^{*} / *$ & $0.304 \pm 0.018$ \\
MSG-group + B. animalis VKL & $0.553 \pm 0.022^{*}$ & $1.166 \pm 0.040^{*}$ & $0.300 \pm 0.011$ \\
MSG-group + B. animalis VKB & $0.583 \pm 0.019^{*}$ & $1.183 \pm 0.077^{*}$ & $0.306 \pm 0.008$ \\
MSG-group + L. casei IMV B-7280 & $0.569 \pm 0.022^{*}$ & $1.178 \pm 0.101^{*}$ & $0.299 \pm 0.008$ \\
\hline
\end{tabular}

$* \mathrm{P}<0.05$ compared with intact rats, $* * \mathrm{P}<0.05$ compared with MSG-group

with intact rats. That may indicate decreasing the expression of this pro-inflammatory cytokine in the case of treating with the $B$. animalis VKL - B. animalis VKB - L. casei IMV B-7280 composition.

The level of the IL-12B p40 in blood serum was decreased after administration of the $B$. animalis VKL - B. animalis VKB - L. casei IMV B-7280 composition $(18.9 \%, \mathrm{P}<0.05)$ and $B$. animalis VKL $(10.5 \%, \mathrm{P}<0.05)$ vs the MSG-group. However, the level of the IL$12 \mathrm{~B} \mathrm{p} 40$ in blood serum of these rats remained higher than in intact animals. B. animalis VKB and L. casei IMV B-7280 did not affect the level of this pro-inflammatory cytokine in blood serum of obese rats, which exceeded these indicators in intact rats. As shown in Table 1, the interferon- $\gamma$ production was not changed after the administration of the probiotic strains and probiotic composition to obese rats. Therefore, the interferon- $\gamma$ level remained on the level of this cytokine in blood serum of the MSG-group and the control group.

In the case of MSG-induced obesity, the level of anti-inflammatory cytokines such as IL-4, IL-10 and TGF- $\beta$ in blood serum significantly reduced $(30.6 \% ; 28.5 \%$ and 14.9 $\%$, respectively, $\mathrm{P}<0.05)$ comparing with intact rats (Table 2). This data indicates a weakening of the body's ability to resist inflammation under this pathology.

The IL-4 level in blood serum increased under the influence of $B$. animalis VKL (on $21.7 \%, \mathrm{P}<0.05), B$. animalis VKB and L. casei IMV B-7280 (18.0\%, P < 0.05) (separately) and the probiotic composition $(27.2 \%, \mathrm{P}<$ 0.05) comparing with the MSG-group. After administration of the probiotic composition to obese rats, the IL-4 level increased to the level of this cytokine in blood serum of intact animals. However, while using $B$. animalis VKL, B. animalis VKB or L. casei IMV B-7280 separately the level of this anti-inflammatory cytokine was lower than in intact animals.

Studying the IL-10 production in animals with MSG-induced obesity, we found a similar tendency. Thus, the level of this anti-inflammatory cytokine in blood serum increased under the influence of B. animalis VKL, B. animalis $\mathrm{VKB}$ and the probiotic composition comparing with the MSG-

Table 2. Concentration of the anti-inflammatory cytokines in the serum of the obese rats $(M+m, n=10)$

\begin{tabular}{|c|c|c|c|}
\hline \multirow{2}{*}{ Groups of the rats } & \multicolumn{3}{|c|}{ Level of the cytokines in serum, $\mathrm{pg} / \mathrm{ml}$} \\
\hline & IL-4 & IL-10 & TGF- $\beta$ \\
\hline Intact rats & $0.446 \pm 0.026$ & $0.311 \pm 0.014$ & $0.374 \pm 0.019$ \\
\hline MSG-group & $0.309 \pm 0.017^{\star}$ & $0.222 \pm 0.013^{*}$ & $0.318 \pm 0.020^{*}$ \\
\hline MSG-group + probiotic composition & $0.393 \pm 0.018^{\star *}$ & $0.334 \pm 0.020^{\star *}$ & $0.399 \pm 0.026^{* *}$ \\
\hline MSG-group + B. animalis VKL & $0.376 \pm 0.018^{*} /^{* *}$ & $0.280 \pm 0.008^{*} / * *$ & $0.381 \pm 0.018^{* *}$ \\
\hline MSG-group + B. animalis VKB & $0.331 \pm 0.014^{*}$ & $0.284 \pm 0.018^{* *}$ & $0.324 \pm 0.011^{\star}$ \\
\hline MSG-group + L. casei IMV B-7280 & $0.365 \pm 0.014^{\star} / * *$ & $0.260 \pm 0.024^{*}$ & $0.359 \pm 0.013$ \\
\hline
\end{tabular}

$* \mathrm{P}<0.05$ compared with intact rats, $* * \mathrm{P}<0.05$ compared with MSG-group 
group $(26.0 \% ; 27.6 \%$ and $50.0 \%$, respectively, $\mathrm{P}<0.05)$. However, L. casei IMV B-7280 did not affect the IL-10 production.

The TGF- $\beta$ level was increased in blood serum of obese rats which received the probiotic composition $(25.5 \%, \mathrm{P}<0,05)$ or $B$. animalis VKL (on $19.8 \%, \mathrm{P}<0.05$ ) comparing with the MSG-group. B. animalis VKB had no significant effect on the level of this anti-inflammatory cytokine, which was lower $(13.2 \%, \mathrm{P}<0.05)$ than in intact animals. The TGF- $\beta$ production in rats with $\mathrm{MSG}$-induced obesity was not changed under the influence of $L$. casei IMV B-7280. It should be noted that the amount of the IL-4, IL-10 and TFG- $\beta$ increased to the levels in intact rats only after administration of the probiotic compositions to MSG-obese rats, but not probiotic strains separately.

Hence, our results suggest the anti-inflammatory effect of $B$. animalis VKL, B. animalis VKB and L. casei IMV B-7280 (separately) and the B. animalis VKL - B. animalis VKB - L. casei IMV B-7280 composition in rats with MSGinduced obesity. Nevertheless, the most pronounced effect was obtained after administration of the B. animalis VKL - B. animalis VKB - L. casei IMV B-7280 composition to obese rats, it reduced the level of pro-inflammatory cytokines such as IL- $1 \beta$ and IL-12Br40 comparing with the MSG-group and restored the level of anti-inflammatory cytokines such as IL-4, IL-10 and TGF- $\beta$ to the levels in intact rats. This data indicates the strong anti-inflammatory effect of the B. animalis VKL - B. animalis VKB - $L$. casei IMV B-7280 composition in the case of administration it to MSG-obese rats.

We had previously shown [16] such biomarkers of MSG-induced visceral obesity in newborn rats: increased body mass index, Lee index, mass of the visceral adipose tissue and decreased body length; abnormalities in the lipid and carbohydrate metabolism as well as decreased adiponectin level in blood serum and increased leptin level in adipose tissue.In this study, we established that neonatal administration of MSG to newborn rats lead to increased pro-inflammatory cytokines production such as IL- $1 \beta$ and IL-12Br40. In contrast, the production of anti-inflammatory cytokines such as IL-4, IL-10, and TGF- $\beta$ in rats with MSG-induced obesity decreased. Our results indicated the inflammation development in rats with MSGinduced obesity. It should be noted that in the case of obesity, chronic low-grade inflammation, which comes out in increased levels of acutephase proteins and pro-inflammatory mediators in blood serum [18], plays a critical role in the development of cardiovascular dysfunction [19], insulin resistance and type II diabetes [7,20].

It was found that the IL-1 $\beta$, which is primed by high-fat diet (HFD) and is cleaved through the NLRP3 inflammasome complex [21, 22], and which production in fat tissue is associated with the TLR4 receptor and nuclear factor$\kappa \mathrm{B}$ activation $[23,24]$, directly influences the peripheral insulin resistance and type II diabetes $[20,25,21,26,22]$. In our study, glucose and insulin levels in blood serum, and HOMA insulin resistance index [16], as well as IL-1 $\beta$ and IL-12Br40 production were also increased in rats with MSG-induced obesity comparing with intact rats. These parameters of carbohydrate metabolism indicate the development of insulin resistance and type II diabetes in rats with MSGinduced obesity, which is connected with lowgrade inflammation development.

As we demonstrated, probiotic strains $L$. casei IMV B-7280, B. animalis VKL and $B$. animalis VKB and the $B$. animalis VKL $-B$. animalis VKB - L. casei IMV B-7280 composition are able to improve some biomarkers of MSG-induced visceral obesity in Wistar male rats: anthropometric parameters were improved, mass of the visceral adipose tissue was decreased, lipid and carbohydrate metabolism was improved, adiponectin level was increased, and leptin level in adipose tissue was decreased comparing with the MSG-group. The probiotic composition more effectively prevents monosodium glutamate-induced obesity in rats [16].

In this article, we are describing results of the study, which demonstrate that improving 
MSG-induced visceral obesity biomarkers in rats under the influence of L. casei IMV B-7280, B. animalis VKL and B.animalis VKB (separately) and their composition is accompanied with changes in pro- (IL-1 $\beta$, IL-12Br40) and antiinflammatory (IL-4, IL-10, TGF- $\beta$ ) cytokines production. While using the $B$. animalis VKL - B. animalis VKB - L. casei IMV B-7280 composition for treatment we observed a tendency towards decreasing of the IL- $1 \beta$ production and significant decreasing of the IL-12Br40 production in the MSG-group comparing with rats with MSG-obesity which did not receive the probiotic composition. However, the level of the IL-4, IL-10 and TGF- $\beta$ production increased (vs the level in intact rats). But the application of $L$. $c a$ sei IMV B-7280, B. animalis VKL, B. animalis VKB (separately) for therapeutic purposes was less effective. These results suggested that the B. animalis VKL - B. animalis VKB - L. casei IMV B-7280 composition is able to restore the inflammation in rats with MSG-induced obesity, but in order to reduce chronic inflammation we need a prolonged use. The anti-inflammatory effect of probiotic bacteria correlated with decreasing of the visceral fat mass as well as a warning to development of the insulin resistance and type II diabetes development in MSG-induced obesity, as well as improved lipid metabolism comparing with rats which were not treated using probiotic bacteria.

Therefore, as we recently established, glucose and insulin levels in blood serum and HOMA insulin resistance index in the MSGgroup dropped under the influence of probiotic bacteria, but the insulin level in blood serum and HOMA insulin resistance index did not restore to those levels in intact animals [16]. Under the influence of probiotic strains and probiotic composition total cholesterol, very low-density lipoprotein and high-density lipoprotein levels decreased, and the low-density lipoprotein level increased comparing with those in the MSG-group. However, the total cholesterol level reduced to the control level only after using the probiotic composition for treatment.
The triglycerides level reduced comparing with the MSG-group only under the influence of the probiotic composition and L. casei IMV B-7280.

In the case of MSG-obesity the $B$. animalis VKL - B. animalis VKB - L. casei IMV B-7280 composition has a stronger effect on carbohydrate and lipid metabolism parameters as well as stronger anti-inflammatory effect comparing with probiotic bacteria (separately). We also found [16] decreased leptin concentration in adipose tissue in rats with MSG-induced obesity which received this probiotic composition. But the adiponectin concentration in blood serum of these rats was not changed. In the case of MSGobesity in rats, the anti-inflammatory effect of the $B$. animalis VKL - B. animalis VKB - L. case IMV B-7280 composition and probiotic bacteria (separately) perhaps related to gut microbiota modulating, but further studies are required to depose to this fact.

According to other authors [27], in the case of high fat diet-induced obesity in young male Sprague-Dawley rats, a probiotic, VSL \#3 (a multistrain preparation composed of Streptococcus thermophillus and several species of Lactobacillus and Bifidobacteria) has anti-oxidative and anti-inflammatory effects, accompanied with the alteration of the lipid peroxidation and lipid metabolism. L. sakei OK67 improves high-fat diet (HFD)induced obesity in mice and hyperglycemia by reducing inflammation through suppression the HFD-induced TNF- $\alpha$ and IL- $1 \beta$ expression and nuclear factor $-\kappa \mathrm{B}$ activation in the colon as well as inhibiting the nuclear factor- $\kappa \mathrm{B}$ activation in LPS-stimulated peritoneal macrophages [23]. $L$. casei str. Shirota also shows anti-inflammatory effects in young and old obese rats through changes in the IGFBP-3, IL-6, and IL-12 levels [28]. The pro-inflammatory IL-12, IFN- $\gamma$ and TNF- $\alpha$ cytokine production decreases and antiinflammatory IL-10 cytokine secretion increases after administration of L. plantarum TN8 to obese rates, which correlates with improving in hepatic and urinary functions of these rats through inducing the decrease in alanine 
aminotransferase, gamma glutamyl transferase, plasmatic triglycerides, total cholesterol concentrations, creatinine, urea, and body [29].

Our data confirm multiple mechanisms of therapeutical effects of probiotic strains $L$. casei IMV B-7280, B. animalis VKL and B.animalis $\mathrm{VKB}$ and the $B$. animalis VKL - B. animalis VKB - L. casei IMV B-7280 composition in rats with $\mathrm{MSG}$-induced obesity. The probiotic composition was more effective than probiotic strains separately. We can explain this by the fact that all markers of obesity that we studied, including pro- and anti-inflammatory cytokine production, effectively improved only after using the probiotic composition in order to treat rats with obesity. These data suggest the feasibility of developing recommendations for inclusion of $B$. animalis VKL - B. animalis VKB - L. casei IMV B-7280 probiotic composition in the complex scheme for treating obesity. The ability to alter pro- and anti-inflammatory cytokines production opens new perspectives for the development of probiotic-based treatment for obesity and metabolic syndrome. The immunobiotics in the long term can also be used for the treatment of type II diabetes, cardiovascular diseases, musculoskeletal disorders, liver fibrosis, neurodegenerative diseases, atherosclerosis, and cancer.

Т.М. Фалалссва ${ }^{1}$, І.В. Лещенко ${ }^{1}$, Т.В. Берегова ${ }^{1}$, Л.М. Лазаренко ${ }^{1,2}$, О.М. Савчук ${ }^{1}$, Л.М. Сішел ${ }^{2}$, О.І. Цирюк ${ }^{1}$, Т.В. Вовк ${ }^{1}$, М.Я. Співак ${ }^{2,3}$

\section{ПРОБІОТИЧНІ ШТАМИ ЛАКТОБАЦИЛ ТА БІФІДОБАКТЕРІЙ ЗМІНЮЮТЬ ПРОДУК- ЦІЮ ПРО- ТА ПРОТИЗАПАЛЬНИХ ЦИТО- КІНІВ У ЩУРІВ 3 ОЖИРІННЯМ, ІНДУКО- ВАНИМ ГЛУТАМАТОМ НАТРІЮ}

Метою дослідження було визначення впливу пробіотичних штамів Lactobacillus casei IMB B-7280, Bifidobacterium animalis VKL, B. animalis VKB (окремо) та композиції $B$. animalis VKL - B. animalis VKB - L. casei IMB B-7280 на продукцію про- і протизапальних цитокінів у сироватці крові самців щурів лінії Вістар з ожирінням, індукованим глутаматом натрію (ГН). Встановлено, що неонатальне введення ГН щурам призводило до збільшення вмісту інтерлейкіну (ІЛ)-1 $\beta$ і ІЛ-12Вр40, а також до зменшення ІЛ-4, ІЛ-10 і фактора росту пухлини (ФРП)- $\beta$. Після ве- дення щурам з ожирінням композиції B. animalis VKL - B. animalis VKВ - L. casei IMB В-7280 вміст ІЛ-1 $\beta$ не відрізнявся від такого у щурів з ожирінням, які не отримували пробіотичні бактерії, але не було статистично значущої різниці порівняно 3 інтактними тваринами. Вміст ІЛ12Bp40 зменшувався під впливом композиції B. animalis VKL - B. animalis VKB - L. casei IMB B-7280 (18,9\%; P $<0,05)$ та $B$. animalis VKL $(10,5 \%$; $\mathrm{P}<0,05)$ порівняно зі щурами $з$ ожирінням, що не отримували пробіотичні бактерії, але залишався вищим, ніж в інтактних тварин. Після введення щурами з ожирінням композиції $B$. animalis VKL - B. animalis VKB - L. casei IMB B-7280 та B. animalis VKL вміст ІЛ-4, ІЛ-10 та ФРН- $\beta$ підвищувався порівняно зі щурами з ожирінням, що не отримували пробіотичні бактерії. Вміст ІЛ-10 підвищувався також під впливом $B$. animalis VKB, а ІЛ-4 - під впливом L. casei IMB В-7280. Отримані нами результати свідчать про те, що ці пробіотичні бактерії і пробіотична композиція здатні нормалізувати запалення у щурів з ожирінням, індукованим ГН, проте найсильнішу протизапальну дію мала пробіотична композиція. Здатність лактобацил і біфідобактерій впливати на продукцію про- і протизапальних цитокінів відкриває перспективи для створення нових методів лікування ожиріння і метаболічного синдрому на основі пробіотиків. Ключові слова: ожиріння; глутамат натрію; Lactobacilli; Bifidobacteria; цитокіни; щури.

${ }^{1}$ Київьький національний університет імені Тараса Шевченка;

${ }^{2}$ Інститут мікробіології і вірусології ім. Д.К. Заболотного НАН України, Київ, ${ }^{3}$ ТОВ «Діапроф», Київ

Т.М. Фалалеева ${ }^{1}$, И.В. Лещенко ${ }^{1}$, Т.В. Береговая 1 , Л.Н. Лазаренко ${ }^{1,2}$, А.Н. Савчук ${ }^{1}$, Л.М. Сишел ${ }^{2}$, Е.И. Цирюк ${ }^{1}$, Т.В. Вовк ${ }^{1}$, Н.Я. Спивак ${ }^{2,3}$

ПРОБИОТИЧЕСКИЕ ШТАММЫ ЛАКТОБАЦИЛ И БИФИДОБАКТЕРИЙ ИЗМЕНЯЮТ ПРОДУКЦИЮ ПРО- И ПРОТИВОВОСПАЛИТЕЛЬНЫХ ЦИТОКИНОВ У КРЫС С ОЖИРЕНИЕМ, ИНДУЦИРОВАННЫМ ГЛУТАМАТОМ НАТРИЯ

Целью исследования было определение влияния пробиотических штаммов Lactobacillus casei ИМВ В-7280, Bifidobacterium animalis VKL, B. animalis VKB (отдельно) и композиции B. animalis VKL - B. animalis VKB - L. casei ИМВ В-7280 на продукцию про- и противовоспалительных цитокинов в сыворотке крови у самцов крыс линии Вистар с ожирением, индуцированным глутаматом натрия (ГН). Установлено, что неонатальное введение ГН крысам приводило к увеличению содержание интерлейкина (ИЛ)$1 \beta$ и ИЛ-12Вр40, а также к уменьшению уровня ИЛ-4, ИЛ-10 и фактора роста опухоли (ФРО)- $\beta$. После введения крысам с ожирением композиции $B$. animalis VKL - B.

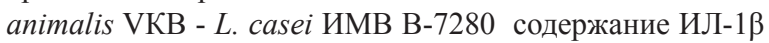


не отличался от такового у крыс с ожирением, которые не получали пробиотические бактерии, но не было статистически достоверной разницы по сравнению с интактными животными. Уровень ИЛ-12Вр40 уменьшался под влиянием композиции $B$. animalis VKL - B. animalis VKB - L. casei ИМВ В-7280 $(18,9 \%$; Р <0,05) или B. animalis VKL $(10,5 \% ; \mathrm{P}<0,05)$ по сравнению с крысами с ожирением, не получавшими пробиотические бактерии, но оставался выше, чем у интактных животных. После введения крысами с ожирением композиции B. animalis VKL - B. animalis VKВ - L. casei ИМВ В-7280 или B. animalis VKL содержание ИЛ-4, ИЛ-10 и ФРО- $\beta$ повышалося по сравнению с крысами с ожирением, не получавших пробиотические бактерии. Уровень ИЛ-10 повышался также под влиянием B. animalis VKВ, а ИЛ-4 - под влиянием L. casei ИМВ B-7280. Полученные нами результаты свидетельствуют о том, что эти пробиотические бактерии и пробиотическая композиция способны нормализировать воспаления у крыс с ожирением, индуцированным ГН, однако более сильное противовоспалительное действие имела пробиотическая композиция. Способность лактобацилл и бифидобактерий влиять на продукцию про- и противовоспалительных цитокинов открывает перспективы для создания новых методов лечения ожирения и метаболического синдрома на основе пробиотиков.

Ключевые слова: ожирение; глутамат натрия; Lactobacilli; Bifidobacteria; цитокины; крысы.

${ }^{1}$ Киевский национальный университет им. Тараса Шевченка;

${ }^{2}$ Институт микробиологии и вирусологии им. Д.К. Заболотного НАН Украины, Киев;

${ }^{3} \mathrm{OOO}$ «Диапроф», Киев

\section{REFERENCES}

1. Alberti KG, Zimmet P, Shaw J. The metabolic syndrome - a new worldwide definition. Lancet. 2005; 366 (9491): 1059-62

2. Boulangé CL, Neves AL, Chilloux J, Nicholson JK, Dumas ME. Impact of the gut microbiota on inflammation, obesity, and metabolic disease. Genome Med. 2016; 8 (1): 42. doi: 10.1186/s13073-016-0303-2.

3. Esposito Emanuela, Anna Iacono, Giuseppe Bianco, Autore G, Cuzzocrea S, Vajro P, et al. Probiotics reduce the inflammatory response induced by a high-fat diet in the liver of young rats. J. Nutr. 2009; 139 (5): 905-11.

4. Bastard JP, Maachi M, Lagathu C, Kim MJ, Caron M, Vidal $\mathrm{H}$, et al. Recent advances in the relationship between obesity, inflammation, and insulin resistance. Eur Cytok Network. 2006; 17 (1): 4-12.

5. Velloso LA, Araújo EP, de Souza CT. Diet-induced inflammation of the hypothalamus in obesity. Neuroimmunomodulation. 2008; 15 (3):189-93.

6. Dallman MF, la Fleur SE, Pecoraro NC, Gomez F, Houshyar H, Akana SF. Minireview: glucocorticoids-food intake, abdominal obesity, and wealthy nations in 2004.
Endocrinology. 2004; 145 (6): 2633-38.

7. Deng T, Lyon CJ, Minze LJ, Lin J, Zou J, Liu JZ, et al. Class II major histocompatibility complex plays an essential role in obesity-induced adipose inflammation. Cell Metab. 2013; 17 (3): 411-22.

8. Glantz Stanton A., Primer of Biostatistics. 4th ed., McGraw-Hill Inc., New York; 1997. Lee B-C, Lee J. Cellular and molecular players in adipose tissue inflammation in the development of obesity-induced insulin resistance. Biochim Biophys Acta. 2014; 1842 (3): 446-62.

9. Esser N, Legrand-Poels S, Piette J, Scheen AJ, Paquot $\mathrm{N}$. Inflammation as a link between obesity, metabolic syndrome and type 2 diabetes. Diabet Res Clinical Pract. 2014; 105 (2): 141-50.

10. Jung SH, Park HS, Kim KS, Choi WH, Ahn CW, Kim BT, et al. Effect of weight loss on some serum cytokines in human obesity: increase in IL-10 after weight loss. J Nutr Biochem. 2008; 19 (6): 371-75.

11. Musso G, Gambino R, Cassader M. Obesity, diabetes, and gut microbiota: the hygiene hypothesis expanded? Diabet Care. 2010; 33 (10): 2277-84.

12. Gomez-Merino D., Drogou C., Guezennec C.Y., Chennaoui M. Effects of chronic exercise on cytokine production in white adipose tissue and skeletal muscle of rats. Cytokine. 2007; 40 (1): 23-9.

13. Guijarro A, Laviano A, Meguid MM. Hypothalamic integration of immune function and metabolism. Prog Brain Res. 2006; 153: 367-405.

14. Aggarwal J, Swami G, Kumar M. Probiotics and their Effects on Metabolic Diseases: An Update. J Clin Diagn Res. 2013; 7(1): 173-77.

15. Lazarenko L, Babenko L, Sichel LS, Pidgorskyi V, Mokrozub V, Voronkova O, et al. Antagonistic action of Lactobacilli and Bifidobacteria in relation to Staphylococcus aureus and their influence on the immune response in cases of intravaginal staphylococcosis in mice. Probiot Antimicr Proteins. 2012; 4 (2):78-89

16. Lim SM, Jeong JJ, Woo KH, Han MJ, Kim DH. Lactobacillus sakei OK67 ameliorates high-fat dietinduced blood glucose intolerance and obesity in mice by inhibiting gut microbiota lipopolysaccharide production and inducing colon tight junction protein expression. Nutr Res. 2016; 36 (4): 337-48..

17. Glantz Stanton A., Primer of Biostatistics. 4th ed., McGraw-Hill Inc., New York; 1997.

18. Cao L, Qin X, Peterson MR, Haller SE, Wilson KA, Hu $\mathrm{N}$, et al. CARD9 knockout ameliorates myocardial dysfunction associated with high fat diet-inducedobesity. J Mol Cell Cardiol. 2016; 92:185-95.

19. Rodríguez-Hernández H, Simental-Mendía LE, Rodríguez-Ramírez G, Reyes-Romero MA. Obesity and inflammation: epidemiology, risk factors, and markers of inflammation. Int J Endocrinol. 2013; 2013:678159. doi: 10.1155/2013/678159. Epub 2013 Apr 17.

20. Masters SL, Dunne A, Subramanian SL. Hull RL, Tannahill GM, Sharp FA, et al. Activation of the NLRP3 inflammasome by islet amyloid polypeptide provides a 
T.M. Falalyeyeva, I.V. Leschenko, T.V. Beregova, L.M. Lazarenko, O.M. Savchuk, L.M. Sichel, O.I. Tsyryuk, T.B. Vovk, M.Ya. Spivak

mechanism for enhanced IL-1 $\beta$ in type 2 diabetes. Nat. Immunol. 2010; 11 (10): 897-904.

21. Stienstra R, Joosten LA, Koenen T, van Tits B, van Diepen JA, van den Berg SA, et al. The inflammasome-mediated caspase-1 activation controls adipocyte differentiation and insulin sensitivity. Cell Metab. 2010; 12 (6): 593-605.

22. Kaya MS, Bayıroglu F, Mis L, Kilinc D, Comba B. In case of obesity, longevity-related mechanisms lead to anti-inflammation. Age (Dordr). 2014; 36 (2): 677-87.

23. Savcheniuk OA, Virchenko OV, Falalyeyeva TM, Babenko LP, Lazarenko LM et al. The efficacy of probiotics for monosodium glutamate-induced obesity: dietology concerns and opportunities for prevention. EPMA J. 2014; 5:2 doi:10.1186/1878-5085-5-2.

24. Yang W, Cao M, Mao X, Wei X, Li X, Chen G, et al. Alternate-day fasting protects the livers of mice against high-fat diet-induced inflammation associated with the suppression of Toll-like receptor 4/nuclear factor $\mathrm{\kappa B}$ signaling. Nutr Res. 2016; 36 (6): 586-93.
25. Vandanmagsar B, Youm YH, Ravussin A, Galgani JE, Stadler K, Mynatt RL, et al. The NLRP3 inflammasome instigates obesity-induced inflammation and insulin resistance. Nat Med. 2011; 17 (2): 179-88.

26. Finucane OM, Lyons CL, Murphy AM, Reynolds CM, Klinger R, Healy NP, et al. Monounsaturated fatty acid-enriched high-fat diets impede adipose NLRP3 inflammasome-mediated IL- $1 \beta$ secretion and insulin resistance despite obesity. Diabetes. 2015; 64 (6): 2116-28.

27. Lalitha V, Pal GK, Pal P, Babu MS. Neuroimmunomodulation in obesity. Internat J Clin Exp Physiol. 2015; 2(2): 97-102.

28. Wen H, Gris D, Lei Y, Jha S, Zhang L, Huang MT, et al. Fatty acid-induced NLRP3-ASC inflammasome activation interferes with insulin signaling. Nat Immunol. 2011; 12 (5): 408-15.

29. Salah Ben R, Trabelsi I, Hamden K, Chouayekh H, Bejar S. Lactobacillus plantarum TN8 exhibits protective effects on lipid, hepatic and renal profiles in obese rat. Anaerobe. 2013; 23: 55-61. 